LINGUODIDACTICA XXII

DOI: 10.15290/lingdid.2018.22.12

\author{
dr Edyta Wajda \\ Uniwersytet w Białymstoku \\ Wydział Filologiczny, Instytut Neofilologii \\ tel. (85) 7457516 \\ e-mail: e.wajda@uwb.edu.pl \\ ORCID ID: https://orcid.org/0000-0002-0042-0414
}

\title{
PRE-SERVICE TEACHERS' PERCEPTIONS OF THE USEFULNESS OF THE EUROPEAN PORTFOLIO FOR STUDENT TEACHERS OF LANGUAGES
}

\begin{abstract}
STRESZCZENIE
OPINIE STUDENTÓW FILOLOGII ANGIELSKIEJ NA TEMAT UŻYTECZNOŚCI EUROPEJSKIEGO PORTFOLIO DLA STUDENTÓW - PRZYSZŁYCH NAUCZYCIELI JĘZYKÓW

Od lat osiemdziesiątych zarówno w edukacji językowej jak i w kształceniu nauczycieli następuje stopniowe przechodzenie od tradycyjnego testowania do alternatywnych form oceniania (portfolia, dzienniki, wywiady, itp.). Artykuł przedstawia wyniki badania sondażowego przeprowadzonego wśród studentów III roku filologii angielskiej na Uniwersytecie w Białymstoku, którego celem było ustalanie, jak postrzegają oni przydatność samooceny umiejętności dydaktycznych i stosowanie Europejskiego Portfolio dla studentów - przyszłych nauczycieli języków. Wyniki wskazują, że badani studenci wysoko oceniają przydatność samooceny umiejętności dydaktycznych, lecz mniej pozytywnie oceniają swoje kompetencje w tym zakresie.
\end{abstract}

Słowa kluczowe: Europejskie Portfolio dla studentów - przyszłych nauczycieli języków, samoocena, kompetencje dydaktyczne

\section{SUMMARY}

Since the 1980s we have observed a gradual shift from traditional testing to alternative forms of assessment (portfolios, diaries, interviews, etc.) both in the language education and teacher training. This article presents the results of a survey study on the pre-service teachers' perceptions of the usefulness and feasibility of assessing their didactic skills and the application of the European Portfolio for Student Teachers of Languages. The study was 
conducted among the third year students of English at the University of Białystok. The results of the research indicate that the students under investigation perceive self-assessment of their teaching skills as beneficial; however, they show less favourable opinions about their own competences in this area.

Key words: the European Portfolio for Student Teachers of Languages, self-assessment, didactic competences

\section{Introduction}

Since the early 1980s language education and language research have been affected by conceptual and methodological changes that are usually termed a paradigm shift. The most influential way of interpreting the characteristics of the change can be attributed to 'Kuhnian-inspired paradigm talk', which defines the shift as a transition from the positivist paradigm to interpretivist conceptual frameworks. In particular, the shift has been characterised as a move from a transmission model of teaching, concordant with the positivist paradigm, towards a learner-centred pedagogy or experiential paradigm, which reflects the interpretivist perspective. The key components of the transition include, inter alia, the following aspects:

- learner empowerment, which has resulted in a move from teachercentred instruction to learner-centred instruction;

- the requirement of authenticity, which has changed a focus on teaching discrete-point items into a focus on learning language for communication;

- an emphasis on learning processes, which has inspired a move from product-oriented instruction to process-oriented instruction;

- the rise of 'assessment culture', which has triggered a change from traditional testing to alternative methods of assessment ${ }^{2}$.

The methodology of language teacher education has been affected by the same paradigm changes as language pedagogy ${ }^{3}$. Therefore, at the pre- and inservice levels, there has appeared a tendency to implement a growing number of

1 R. Donmoyer, Paradigm talk reconsidered, [w:] Handbook of research on education, V. Richardson (red.), Washington, D.C. 2002.

2 M. Legutke, H. Thomas, Process and experience in the language classroom, Harlow 1993; G.M. Jacobs, T.S.C. Farrel, Paradigm shift: understanding and implementing change in second language education, „TESL-EJ” 2015, 5(1); W. Littlewood, Process-oriented pedagogy: facilitation, empowerment, or control?, „ELT Journal” 2009, 63(3), s. 246-254.

3 K.E. Johnson, The second language teacher education: a sociocultural approach, New York 2009; B.K. Lynch, Language program evaluation: theory and practice, New York 1996. 
alternative assessment methods, including teacher journals and diaries, portfolios, observation, interviews, conferences, case and critical incidents studies ${ }^{4}$. The core of the majority of these methods is constituted by self-reflection on and self-assessment of the products and processes of learning. This tendency can be attributed to adopting interpretivist frameworks of teacher education and teacher evaluation programmes, which foster the model of a teacher as a reflective practitioner ${ }^{5}$ and new research perspectives stimulated by a growing interest in teacher cognition and its impact on teacher development and practice ${ }^{6}$.

Teacher self-assessment is perceived in two ways - as a process leading to reflexivity and thereby enhancing the development of a teacher as an individual ${ }^{7}$ or as a process of modelling one's professional practice to optimise its effects. While the latter perspective has an undeniable pragmatic value, limiting teacher self-assessment to such an instrumental objective might undermine its primary purpose and result in various misuses, such as incorporating it into human resources management schemes in school evaluation systems ${ }^{8}$. Therefore, teacher self-assessment should be implemented in non-threatening conditions and primarily aim at the teacher's professional and individual development.

Among alternative assessment instruments employed in pre- and in-service teacher training, portfolios seem to be gaining notable significance. In some contexts, they are used for high-stakes purposes as bases for decisions concerning the certification, promotion or formal evaluation of teachers 9 . However, there are objections expressed with reference to the reliability of highstakes portfolios. Moreover, portfolios seem to better adhere to the principles of alternative assessment if they are used to monitor and formatively evaluate teaching in day-to-day professional or interim practice.

4 e.g. Evaluating second language education, J.C. Alderson, A. Beretta (red.), Cambridge 1992; J.C. Richards, T.S.C. Farrel, Professional development for language teachers. Strategies for teacher learning, Cambridge 2005; D. Gabryś-Barker, Appraisal systems in teacher training: focus on critical incidents (CI), „Linguistica Silesiana” 2011, 32, s. 259-274.

5 M. Wysocka, Profesjonalizm w nauczaniu języków obcych, Katowice 2003; E. Zawadzka, Nauczyciele języków obcych $w$ dobie przemian, Kraków 2004; H. Komorowska, Samoocena w kształceniu $i$ doskonaleniu nauczycieli - nowe rozwiązania europejskie, [w:] Kultury i języki. Poznawać - uczyć się - nauczać, A. Jaroszewska, M. Lorenc (red.), Warszawa 2008, s. 71-80.

6 D. Potocka, Developing professional competence in the process of pre- and in-service teacher education, Unpublished Ph.D. dissertation 2006; K.E. Johnson, The second language teacher education: a sociocultural approach, New York 2009.

7 S.G. Paris, L.R. Ayres, Stawanie się refleksyjnym uczniem i nauczycielem, tłum. M. Janowski, M. Micińska, Warszawa 1997.

8 E. Wajda, Samoocena nauczyciela języków obcych, [w:] Skuteczna nauka języka obcego. Struktura i przebieg zajęć językowych, H. Komorowska (red.), Warszawa 2009, s. 71-80.

9 e.g. R. Attinello, D. Lare, F. Waters, The value of teacher portfolios for evaluation and professional growth, „NASSP Bulletin” 2006, 90(132), s. 132-152. 


\section{The European Portfolio for Student Teachers of Languages - a tool for assessing didactic ability}

The European Portfolio for Student Teachers of Languages $(E P O S T L)^{10}$ is a tool developed by the Council of Europe with the aim of fostering teacherlearner autonomy ${ }^{11}$ in students undergoing initial language teacher education. Specifically, the EPOSTL encourages students to reflect on their didactic knowledge and skills, assists them in the processes of self-assessment as well as enables them to monitor their progress and record their teaching experiences ${ }^{12}$. The portfolio belongs to the student-teacher and as such cannot be used for formal assessment or any form of certification. The main aims of the EPOSTL are formulated as follows:

- to encourage student teachers to reflect on the competences a teacher strives to attain and on the underlying knowledge which feeds these competences;

- to help them prepare for their future profession in a variety of teaching contexts;

- to promote discussion between them and their peers and between them and their teacher educators and mentors;

- to facilitate self-assessment of their developing competence;

- to provide an instrument which helps chart progress ${ }^{13}$.

According to Komorowska ${ }^{14}$, the aims of the EPOSTL support the process of "learning to teach", which can lead to student-teachers' developing greater degrees of autonomy in their prospective teaching practice. In practice, the main objective of the EPOSTL is to "provide training in self-regulation, i.e. help students to plan, evaluate and monitor their own work so that they should not remain dependent on teachers".

The EPOSTL is clearly structured and contains the following main sections:

10 D. Newby, R. Allan, A-B. Fenner, B. Jones, H. Komorowska, K. Soghikyan, The European Portfolio for Student Teachers of Languages, Strasbourg 2007.

11 R. Smith, Starting with ourselves: teacher-learner autonomy in language learning, [w:] Learner autonomy, teacher autonomy: Future directions, B. Sinclair, I. McGrath, T. Lamb (red.), Harlow 2000, s. 89-99.

12 D. Newby, R. Allan, A-B. Fenner, B. Jones, H. Komorowska, K. Soghikyan, The European Portfolio for Student Teachers of Languages. Strasbourg 2007, s. 5.

13 Ibidem, s. 5 .

14 H. Komorowska, Learner autonomy and its implications for the EPOSTL, [w:] Insights into the European Portfolio for Student teachers of Languages (EPOSTL), D. Newby (red.), Cambridge 2012, s. 74 . 
- a personal statement section, which allows for reflection on general issues related to teaching;

- a self-assessment section, consisting of 'can-do' descriptors, which is meant to facilitate reflection and self-assessment;

- a dossier, which allows for collecting work samples and artefacts related to teaching ${ }^{15}$.

The self-assessment section provides a list of key didactic competences, which are divided into seven categories: context, methodology, resources, lesson planning, conducting a lesson, independent learning and assessment of learning ${ }^{16}$.

\section{The research methodology and context}

This article reports on the part of research conducted among pre-service teachers of English at the University of Białystok. This study attempted to answer the following research questions:

1. How do the student-teachers under investigation perceive the usefulness of the EPOSTL?

2. What is the student-teachers' competence in self-assessment?

The data was collected with the use of a semi-structured questionnaire, including 3 scale items and 3 open questions, in which the respondents were asked to provide comments concerning the relevant question.

173 third year BA students volunteered to participate in the study. The sample consisted of two groups of respondents:

1. 107 students $(61.8 \%)$ who were in the third year of BA studies in the academic years 2007/2008 and 2008/2009,

2. 66 students (38.2\%) who were in the third year of BA studies in the academic years from 2009 to 2018 .

For the first group of students, the second and the third year methodology courses amounting to 120 hours of teaching were obligatory. Also, the students were obliged to complete a pedagogical and psychological module and were expected to submit a BA thesis which involved the pedagogical implications of the issues studied. All of them gained formal teaching qualifications upon the completion of their studies. The second group within the sample consisted of students who chose to complete an applied linguistics specialisation module in their final year at university, as in the academic year 2009/2010 a choice was

15 D. Newby, R. Allan, A-B. Fenner, B. Jones, H. Komorowska, K. Soghikyan, The European Portfolio for Student Teachers of Languages, Strasbourg 2007, s. 5.

16 Ibidem, s. 6. 
allowed among three specialisations: second language acquisition, linguistics, and cultural/literary studies. So far, following the introduction of the new scheme of study, the pedagogical specialisation has been the least popular among the third year students, which is reflected in the smaller size of the second group within the investigated sample.

Prior to the survey, all respondents had completed a language assessment course or a language assessment module, which formed part of the general methodology course in the third year. The students were familiarised with the features and methods of both traditional and alternative assessment. With respect to the latter, a particular emphasis was placed on documents of the Council of Europe which promote self-assessment. The students were acquainted with the aims of the Common European Framework for Languages $(C E F R)^{17}$; in particular, in using common European levels to assess levels of proficiency in languages. They were also introduced to the idea of the European Language Portfolio $(E L P)^{18}$ and were able to study a Polish version of the document. In the next stage, the respondents were familiarised with the European Portfolio for Student Teachers of Languages (EPOSTL) and were asked to conduct self-assessment of their didactic skills in some selected areas indicated in the portfolio.

\section{Results and discussion}

As it seemed important to explore the students' opinions about both self-assessment of didactic competences in general and a specific instrument in particular, the answers to the first research question were provided by two questionnaire items:

- I find it useful to conduct self-assessment of my didactic knowledge and skills.

- I think that the EPOSTL should be recommended for use in pre-service teacher education in Poland.

To explore the students' attitudes towards self-assessment of didactic knowledge and skills, data was collected from questionnaire item 3 concerning their opinions about the usefulness of conducting self-assessment. The quantitative and qualitative analysis of the results generated by the item is presented below.

17 Common European Framework of Reference for Languages: Learning, Teaching, Assessment, Council of Europe, Cambridge 2001.

18 B. Głowacka, D. Kofman, D. Ryciuk, E. Wajda, D. Żmudzka, Europejskie portfolio językowe dla uczniów od 10 do 15 lat, Warszawa 2004. 
Table 1. Student-teachers' opinions about the usefulness of self-assessment of didactic knowledge and skills

\begin{tabular}{|l|l|c|c|}
\hline \multicolumn{1}{|c|}{ Statement 3 } & & Frequency & Percent \\
\hline $\begin{array}{l}\text { I find it useful to conduct self-assessment of } \\
\text { my didactic knowledge and skills. }\end{array}$ & Strongly disagree & 2 & 1,2 \\
\cline { 2 - 4 } & Disagree & 5 & 2,9 \\
\cline { 2 - 4 } & Difficult to say & 22 & 12,7 \\
\cline { 2 - 4 } & Agree & 106 & 61,3 \\
\cline { 2 - 4 } & Strongly agree & 38 & 22,0 \\
\cline { 2 - 4 } & Total & 173 & 100,0 \\
\hline
\end{tabular}

For the sample, the mean, median and mode values of the respondents' agreement with the statement were 4,00 (std. deviation=0.755), 4,00 and 4 respectively, where 3 indicated difficult to say and 4 indicated agree. There were no significant differences between the groups with respect to the respondents' perceptions of the usefulness of self-assessment as shown by the Mann-Whitney test $(\mathrm{U}=3681,0 ; \mathrm{p}=0.590)$.

68 comments were provided by the subjects in response to statement 3; 61 by those who agreed or strongly agreed with the statement, 3 by those who expressed a lack of opinion and 4 by those who disagreed or strongly disagreed with the statement. Two broad categories: emphasizing the benefits of self-assessment and expressing reservations were identified from comments provided by the respondents. The former was further subdivided into: identifying strong and weak points, planning development, raising awareness and facilitating reflection, and raising motivation. The following answers (in the original form) illustrate each category:

1. identifying strong and weak points:

- I agree because ts should monitor their strong and weak points.

- it is good to think about what you've learned and what you have not learned yet in order to improve.

- It gives me feedback about my strong and weak points.

- Assessing myself allows me to understand in what areas I still lack competence.

- Useful not only for a teacher, but also for the pupils. The teacher who is aware of his or her imperfections will have an opportunity of improving them. 
- Self-assessment is interesting because you're asked to write down the bitter truth about yourself and it can show what is your approach.

2. planning development:

- It also helps to establish clear aims in advancing one's didactic competence.

- It's useful to plan and direct the course of future practice.

- Being able to do so gives me more room for conscious development of my teaching skills

- as I can see if I am making progress and check what should be improved, what is troublesome

- It help managing and organising teaching and learning.

- I agree with the statement because in my opinion some self-assessment descriptors may be good indicators how to improve one's way of teaching.

- It can help me in developing my skills and checking on what I should work more.

3. raising awareness and facilitating reflection:

- Didactics is an extremely complex branch of knowledge and for a young teacher is sometimes difficult to put all the theoretical knowledge into practice. Self-assessment is a useful source of reflection and reconsideration of one's work and abilities.

- It makes us reflect on various issues and improve constantly when we're aware of our ignorance in certain matters.

- It raises my awareness.

- It gives me insight in my development.

- Being able to do so gives me more room for conscious development of my teaching skills

- It is crucial for a teacher to be critical as far as knowledge and skills of a teacher go because it helps them to become better and more professional.

4. raising motivation:

- It would motivate me, gives me some feedback of what I already know and where I need to make some improvements.

- Useful in 2 ways: - controlls my knowledge (motivation) - in the moments when everything goes wrong it is written (black on white) that I "can-do" sth!

5. expressing reservations:

- It is useful though it is difficult to be objective.

- I agree, but I don't know whether we all have time for such activities. 
- But only once I know how.

- I did not do that. Ever!

- It is useful, even though we don't have the practice, because it makes me evaluate my abilities as a future teacher.

- It is very useful despite its difficulties. You always know what you achieved and you can show it.

- It would be rather hard for me to assess my knowledge. I'd prefer it to be done by somebody experienced.

- I think it's hard to assess your skills from the theoretical point of view only. The reality does that better.

- Not really, I'd rather use this time on really developing my skills rather than reading longish \& ambiguous descriptors and ticking boxes

The vast majority of the student-teachers investigated (83.3\%) approved of self-assessment as a mode of evaluation as opposed to very few who disapproved (4.1\%). $12.7 \%$ of the respondents were undecided. The analysis of variance reveals that there were no discrepancies between the groups within the sample, which means that both students for whom the methodology specialisation was obligatory and those for whom it was optional were concordant in their opinions.

The analysis of the qualitative part of the item shows that the students pinpointed the following features of self-assessment:

- its diagnostic value (identifying strengths and weaknesses),

- its impact on planning professional development, and

- facilitating reflection and raising awareness.

It is noticeable that few students addressed the issue of the motivational value of alternative assessment (focusing on strong rather than weak points). Also, many of them emphasised that self-assessment may help to identify areas for improvement or weaknesses (cf. Self-assessment is interesting because you're asked to write down the bitter truth about yourself). The reservations that the respondents expressed pertained mostly to some problems with the implementation of self-assessment, such as lack of experience or the fact that it was time consuming.

To investigate the students' perceptions of the EPOSTL, data was collected from questionnaire item 4 concerning their opinions about the usefulness of the portfolio. A quantitative and qualitative analysis of the results generated by the two items is presented below. 
Table 2. Student-teachers' opinions about the usefulness of the EPOSTL

\begin{tabular}{|l|l|c|c|}
\hline \multicolumn{1}{|c|}{ Statement 4} & Frequency & Percent \\
\hline $\begin{array}{l}\text { I think that the EPOSTL should be } \\
\text { recommended for use in pre-service teacher } \\
\text { education in Poland. }\end{array}$ & Strongly disagree & 2 & 1,2 \\
\cline { 2 - 4 } & Disagree & 8 & 4,6 \\
\cline { 2 - 4 } & Difficult to say & 43 & 24,9 \\
\cline { 2 - 5 } & Agree & 100 & 57,8 \\
\cline { 2 - 5 } & Strongly agree & 20 & 11,6 \\
\cline { 2 - 5 } & Total & 173 & 100,0 \\
\hline
\end{tabular}

For the sample, the mean, median and mode values of the respondents' agreement with the statement were 3.74 (std. deviation=0.768), 4.00 and 4 respectively, where 3 indicated difficult to say and 4 indicated agree. There were no significant differences between the groups with respect to the respondents' perceptions of the usefulness of the EPOSTL as shown by the Mann-Whitney test the $(U=4048,0 ; p=0.69)$.

54 comments were provided by the respondents in response to statement 4; 37 by those who agreed or strongly agreed with the statement, 14 by those who were undecided and 3 by those who disagreed or strongly disagreed with the statement. Four categories were identified for comments provided by the respondents: providing arguments for the use of the EPOSTL, emphasizing that the EPOSTL helps raise awareness and facilitates reflection, expressing objections or reservations, and emphasizing lack of obligation. The following answers (in the original form) illustrate each category:

1. providing arguments for the use of the EPOSTL:

- I agree with that, because teachers should learn and be aware of this way of assessment, and know what is required from them in the future job.

- Yes, because students would have the opportunity to think about their needs and goals.

- It is always to do such things like using EPOSTL because with no doubt it may improve our knowledge about teaching/learning.

- This alternative method is useful in a teacher occupation. It brings many beneficial effects. Best to evaluate self progress.

- EPOSTL gives more practical tips concerning the future work as teacher. It is motivating to try to do some progress, make improvements. 
- It should be recommended and popularized in order to convince Polish teachers \& students of its effectiveness.

- because T's role is to evaluate ss' knowledge so T also should evaluate his/her work; if the T can assess his own work he'll find it easier to assess his ss.

- It should because it exposures the teacher to this kind of assessment and shows the alternative to traditional way of teaching.

2. raising awareness and facilitating reflection:

- It makes us reflect on various issues and improve constantly when we're aware of our ignorance in certain matters.

- It raises my awareness.

- It gives me insight in my development.

- it facilitates self-exploration, self-development.

- Being able to do so gives me more room for conscious development of my teaching skills

- It is crucial for a teacher to be critical as far as knowledge and skills of a teacher go because it helps them to become better and more professional. They are aware f their weak and strong points.

3. expressing objections or reservations:

- It does not prove that I can or can't do certain things, it gives me something to think of but does not give reliable results.

- If and only if we have some practice in teaching. At least in private lessons. Otherwise this assessment would not be objective.

- In Poland lots of people have problems with assessing themselves.

- Yes, if such a document should be introduced to use early and we should work with it.

- It might be more usefull for in-service teachers? Though it's very usefull for pre-service teacher as a reference.

- This would greatly complicate giving marks to students and would require a lot of changes in the way that classes are conducted.

- It's very time-consuming

- I don't know in what form it could be used.

- The recommendation usually will not be followed by actual using it.

4. emphasizing lack of obligation:

- Not every person likes working in this way, and he or she can find it useless.

- EPOSTL should not be obligatory for every student but could serve well as an additional tool of self-assessment for those who want to work on their teaching competence. 
- It should be recommended but not imposed

- Should be recommended, as it may help many future-teachers, but it shouldn't be sth every future-teacher must have.

- On the hand it's something new, very good idea for those who want to monitor their personal experience, progress, etc. but on the other hand, should everybody likes it?

The majority of the student-teachers (69.4\%) agreed that the EPOSTL should be recommended for use in pre-service teacher education. Although the number of respondents who opposed this view was small (5.8\%), nearly a quarter of the respondents $(24.9 \%)$ were undecided. The results show that more students expressed their preference for self-assessment in general (83.3\%) than for the specific instrument, which, additionally, generated more doubts with respect to its usefulness. The fact that there were no statistically significant differences between the groups within the sample, suggests the respondents did not differ in their opinions irrespective of the time of their studies or their specialisation.

Most comments provided by the students concentrated on justifying their support for the document. The functions of the EPOSTL that were considered to be beneficial by pre-service teachers related to: support in identifying needs and setting goals (professional development) and increasing awareness of teaching/learning processes (insights into strategies and methods, practical tips, etc.). The data confirms the findings from questionnaire item 3, concerning the usefulness of self-assessment; the respondents seem to demonstrate positive opinions of this mode of assessment.

A number of respondents (9 comments) stated that it was essential to give prospective users of the EPOSTL a choice, as some of them may not find working with this instrument effective or interesting. Since it was emphasised during the research that European portfolios belong to their users and cannot be imposed institutionally, such opinions may suggest that the perception of the assessor as an external element in the process of assessment is deeply rooted in students' minds. The subjects identified a number of problems in support of their objections or reservations with regard to the use of the EPOSTL, such as lack of reliability or impracticality.

The answer to the second research question was collected via questionnaire item 2. Agreement with the following attitude statements in the questionnaire was interpreted as demonstrating the respondents' positive perception of their competence in self-assessment of didactic knowledge and skills:

- I find it easy to conduct self-assessment of my didactic knowledge and skills. 
The quantitative and qualitative analysis of the results generated by the item is presented below.

Table 3. Student-teachers' perceptions of their competence in self-assessment

\begin{tabular}{|l|l|c|c|}
\hline \multicolumn{1}{|c|}{ Statement 2 } & & Frequency & Percent \\
\hline \multirow{3}{*}{$\begin{array}{l}\text { I find it easy to conduct self-assessment of } \\
\text { my didactic knowledge and skills. }\end{array}$} & Strongly disagree & 4 & 2.3 \\
\cline { 2 - 4 } & Disagree & 46 & 26.6 \\
\cline { 2 - 4 } & Difficult to say & 80 & 46.2 \\
\cline { 2 - 4 } & Agree & 39 & 22.5 \\
\cline { 2 - 4 } & Strongly agree & 4 & 2.3 \\
\cline { 2 - 4 } & Total & 173 & 100.0 \\
\hline
\end{tabular}

For the sample, the mean, median and mode values of the respondents' agreement with the statement were 2.96 (std. deviation=0.824), 3.00 and 3 respectively, where 2 indicated disagree and 3 indicated difficult to say. There were no significant differences between the groups with respect to the respondents' perceptions of the usefulness of the EPOSTL as shown by the Mann-Whitney test the $(\mathrm{U}=3205.5 ; \mathrm{p}=0.276)$.

80 comments were provided by the subjects in response to statement $2 ; 13$ by those who agreed with the statement, 42 by those who were undecided and 25 by those who disagreed or strongly disagreed with the statement. The vast majority of the responses pertained to students' doubts or reservations. The following categories were identified for the comments supplied: insufficient teaching experience, lack of objectivity, insufficient experience in self-assessment, and disapproval of self-assessment. The following answers (in the original form) illustrate each category:

1. insufficient teaching experience:

- I think it is hard to comment on your own abilities especially because I have a little teacher experience.

- Difficult to say because I cannot compare my knowledge with practice.

- I do not have much experience but I am optimistic about the future.

- It is quite difficult to evaluate my abilities concerning my didactic knowledge because the only practice which I have are extra-lessons and there is only one person, not whole class of people. But when my teaching practice is concerned I think that I could say something about this topic. 
- It's easier to assess my competences if the particular elements of them have already cropped up at some point in my teaching practice; otherwise it's difficult to predict anything.

- Mostly because I haven't that much time to check it in real life situations in the school.

- It's difficult to say when the contact with learners is concerned. I can only assess my theoretical knowledge because I have to little experience in teaching.

- It is difficult to conduct self-assessment because we as students don't have enough practice (only two weeks at school is not enough). I haven't reflected (as a practice teacher) upon e.g. alternative assessment

- In my opinion, it is difficult to conduct self-assessment of one's didactic knowledge and skills, especially at the early stage of education because of small experience in teaching.

- It depends because of my short experience as a teacher of English. Some aspects would be easy to evaluate, whereas others not really.

2. lack of objectivity:

- because I am subjective in my opinions; it's easy to conduct s-a, however not always very reliable

- It's quite subjective, so it depends on the person whether he or she is able to look at own abilities objectively

- It's difficult to say because we are not objective about our knowledge and skills and we rather see us what we would like to be rather than we are (in terms of knowledge and skills)

- I can't be objective and don't trust such method of self-assessment. I can't say that I assess myself independent of my mood or weather.

- It is difficult for me because what I believe is true for me but may not be objective.

- I don't think I'm the right person to assess my own didactic skills. I don't think my answers would be objective.

- you can't objectively assess your own performance or abilities, or at least it is difficult.

- In my view self-assessment is not as reliable as that form teacher i.e. someone with higher competence perspective. So, that may be easy for me but I do not know if I do it properly.

3. insufficient experience in self-assessment:

- I usually do not think about it, do not practice my self-assessment

- Because during my 'school career' I didn't have any occasion to self-assess my skills 
- I'm not used to that kind of assessment so it's not easy.

- It might be quite difficult when learners do not know the criteria of assessment or don't know how to reflect upon them.

- It takes years to find it easy!

- I have never done it before. I've always depended on my teacher's opinion.

- I don't know enough tools and instruments to assess myself easily. I don't think I am knowledgeable enough to assess myself.

4. disapproval of self-assessment:

- I am not keen on this method. A standard approach is in my opinion more desirable.

- I find it difficult, as I believe I'd rather need somebody to tell me if I'm doing sth right or wrong

Although the vast majority of the respondents declared positive opinions about the value of self-assessment, their perception of the difficulty of this mode of assessment was different. Approximately, one-third of them found selfassessment difficult to conduct (28.9\%), a quarter found it easy (24.8\%) and almost half of them were undecided (46.2\%). The correlational analysis revealed that the respondents who found the ability of self-assessment an important skill tended to better evaluate their own competence in self-assessment and their attitude to the EPOSTL was more positive (Spearman's $\mathrm{rho}=-0.244, \mathrm{p}=0.001$; Spearman's rho $=-0.352, \mathrm{p}=0.00$ ).

Analysis of the qualitative data indicates that the main reason why the students found self-assessment of their didactic knowledge and skills a challenging task was insufficient teaching experience rather than problems with self-evaluation as such. Yet, the conclusion that self-assessment of skills that can be more easily verified in practice would not pose difficulties for the students would be unfounded. The results may suggest that the student-teachers tended to perceive self-assessment descriptors in the EPOSTL as criteria for evaluation, the achievement of which had to be verified empirically. Another distinguishable group of comments pertained to the issue of the objectivity of self-assessment. Some respondents expressed their concerns that one would be biased when evaluating one's own abilities. Concerns about the objectivity of self-assessment appear to be important to the respondents as they were also present in comments obtained from item 4 of the questionnaire (opinions about the EPOSTL). 


\section{Conclusions}

A large number of respondents expressed positive opinions about the usefulness of self-assessment of didactic knowledge and skills (83.3\%) and of the EPOSTL (69.4\%). The students' attitudes have not changed significantly over the last ten years, which indicates that students' beliefs and mindsets do not change fast. The fact that a smaller portion of the respondents identify the EPOSTL as a valuable assessment instrument may be attributed to a comparatively low degree of learner autonomy in the Polish educational context, which results in larger dependence upon teachers both in the learning and the evaluation processes. Taking charge of one's learning is a prerequisite of fully exploiting the possibilities that the instrument offers.

Despite their positive attitude to this alternative form of evaluation, the students expressed concerns with respect to their competence in self-assessment. Many students declared that they perceived their competence in self-assessment as unsatisfactory: nearly one-third of them found self-assessment difficult to conduct $(28.9 \%)$ and nearly half of them (46.2\%) were unable to evaluate their teaching competences. It seems that, to some extent, their perceived difficulties were connected with the subject matter (didactic knowledge and skills) and the instrument used (the EPOSTL) rather than with the method itself.

Insufficient teaching experience was identified by the subjects as the main reason of their perceived difficulties in self-assessment of their didactic knowledge and skills in general and the proper use of the EPOSTL in particular. Their reservations in this respect appear to be justified. The quality of the teaching practice offered to students is not always satisfactory. Their mentor teachers are not awarded sufficient time and financial resources to provide their mentees with proper guidance and more challenging tasks and opportunities (e.g., information technology support). In addition, it seems that the overall pictures of the teacher's competence presented in the EPOSTL is too challenging for pre-service teachers and that the instrument may be used to monitor progress throughout the whole teaching career.

Further research should be conducted to find out what factors affect students' negative perceptions of their competence in self-assessment and their reluctance to employ instruments of self-assessment. Qualitative analysis shows that some respondents express concerns with respect to the reliability of this mode of assessment. This may substantiate the claim that in the Polish educational context the transition from the positivist paradigm towards a learner-centred pedagogy has not been completed yet. 


\section{Bibliography}

Attinello R., Lare D., Waters F., The value of teacher portfolios for evaluation and professional growth, „NASSP Bulletin” 2006, 90(132), s. 132-152.

Common European Framework of Reference for Languages: Learning, Teaching, Assessment, Council of Europe, Cambridge 2001.

Donmoyer R., Paradigm talk reconsidered, [w:] Handbook of research on education, V. Richardson (red.), Washington, D.C. 2002, s. 174-197.

Evaluating second language education, J.C. Alderson, A. Beretta (red.), Cambridge 1992.

Gabryś-Barker D., Appraisal systems in teacher training: focus on critical incidents (CI), „Linguistica Silesiana" 2011, 32, s. 259-274.

Głowacka B., Kofman D., Ryciuk D., Wajda E., Żmudzka D., Europejskie portfolio językowe dla uczniów od 10 do 15 lat, Warszawa 2004.

Jacobs G.M., Farrel T.S.C., Paradigm shift: understanding and implementing change in second language education, „TESL-EJ” 2015, 5(1), [online], http://www.zait.uni-bremen.de/ wwwgast/tesl_ej/ej17/a1.html, [dostęp: 30.07.2018].

Johnson K.E., The second language teacher education: a sociocultural approach, New York 2009.

Komorowska H., Learner autonomy and its implications for the EPOSTL, [w:] Insights into the European Portfolio for Student teachers of Languages (EPOSTL), D. Newby (red.), Cambridge 2012, s. 51-82.

Komorowska H., Samoocena w kształceniu i doskonaleniu nauczycieli - nowe rozwiązania europejskie, [w:] Kultury i języki. Poznawać - uczyć się - nauczać, A. Jaroszewska, M. Lorenc (red.), Warszawa 2008, s. 71-80.

Legutke M., Thomas H., Process and experience in the language classroom, Harlow 1993.

Littlewood W., Process-oriented pedagogy: facilitation, empowerment, or control? „ELT Journal” 2009, 63(3), s. 246-254.

Lynch B.K., Language program evaluation: theory and practice, New York 1996.

Newby D., Allan R., Fenner A-B., Jones B., Komorowska H., Soghikyan K., The European Portfolio for Student Teachers of Languages, Strasbourg 2007, [online], http://archive.ecml.at/ mtp2/fte/pdf/c3_epostl_e.pdf, [dostęp: 30.07.2018].

Paris S.G., Ayres L.R., Stawanie się refleksyjnym uczniem i nauczycielem, tłum. M. Janowski, M. Micińska, Warszawa 1997.

Potocka D., Developing professional competence in the process of pre- and in-service teacher education, Unpublished Ph.D. dissertation, 2006.

Richards J.C., Farrel T.S.C., Professional development for language teachers. Strategies for teacher learning, Cambridge 2005.

Smith R., Starting with ourselves: teacher-learner autonomy in language learning, [w:] Learner autonomy, teacher autonomy: Future directions, B. Sinclair, I. McGrath, T. Lamb (red.), Harlow 2000, s. 89-99.

Wajda E., Samoocena nauczyciela języków obcych, [w:] Skuteczna nauka języka obcego. Struktura i przebieg zajęć językowych, H. Komorowska (red.), Warszawa 2009, s. 71-80.

Wysocka M., Profesjonalizm w nauczaniu języków obcych, Katowice 2003.

Zawadzka E., Nauczyciele języków obcych w dobie przemian, Kraków 2004. 